\title{
Detection of Helicobacter pylori antigen in stool samples for diagnosis of infection in children
}

M. Rafeey ${ }^{1}$ and S. Nikvash ${ }^{2}$

$$
\begin{aligned}
& \text { اختبار الكثف عن مستضلدات الملويَّة البوابيَّة في عينات البراز لتشخيص العلدوى لدى الأطفال }
\end{aligned}
$$

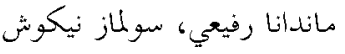

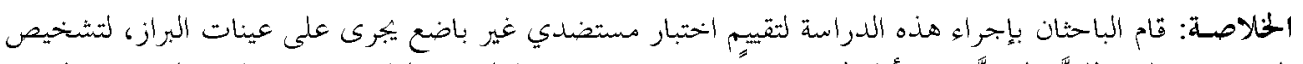

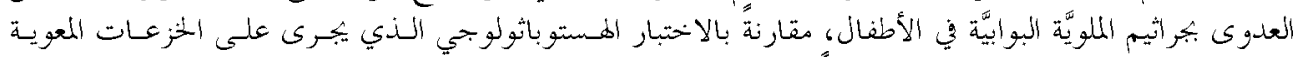

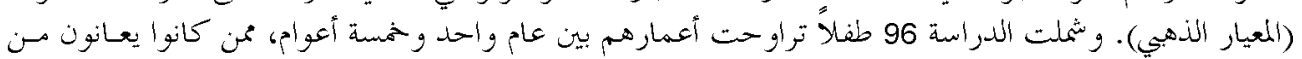

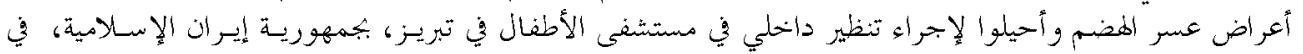

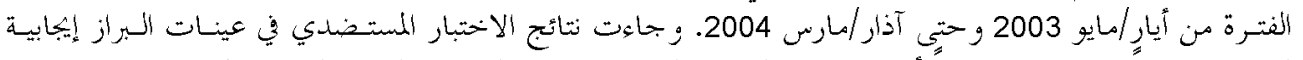

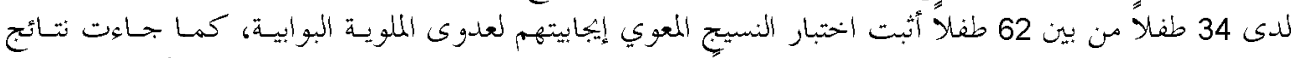

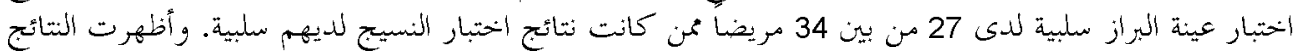

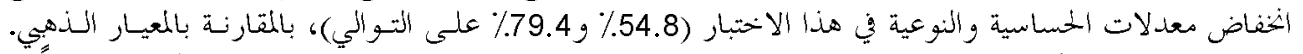

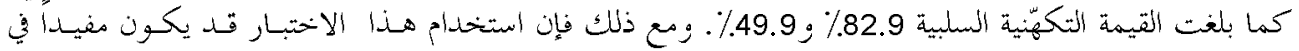

$$
\text { بحال التحري الخموعي لجخرثومة الملوية البوابية. }
$$

ABSTRACT The study evaluated a non-invasive antigen test of stool samples for the diagnosis of Helicobacter pylori infection in children compared with histopathology of gastric biopsies (gold standard). The study included 96 children aged 1-15 years old with dyspeptic symptoms referred for endoscopy at Tabriz Children's Hospital, Tabriz, Islamic Republic of Iran from May 2003 to March 2004. Of 62 children who were positive by histology, 34 were $H$. pylori stool antigen positive and of 34 patients with negative histology, 27 had negative stool test. The sensitivity and specificity of the test were low $(54.8 \%$ and $79.4 \%$ respectively) compared with the gold standard and the positive and negative predictive values were $82.9 \%$ and $49.9 \%$. However, the test may be useful for mass screening for $H$. pylori.

\begin{abstract}
Détection de l'antigène fécal d'Helicobacter pylori pour le diagnostic de l'infection chez l'enfant

RÉSUMÉ Cette étude a évalué un test non invasif de détection de l'antigène fécal d'Helicobacter pylori (HpSA - pour Helicobacter pylori stool antigen) chez l'enfant versus l'histopathologie de biopsies gastriques (la norme en l'espèce). Ont été inclus dans l'étude 96 enfants âgés de 1 à 15 ans adressés entre mai 2003 et mars 2004 à l'hôpital pour enfants de Tabriz, en République islamique d'Iran, pour endoscopie sur présentation de symptômes dyspeptiques. Sur les 62 enfants positifs à l'histologie, 34 se sont avérés HpSA-positifs tandis que sur les 34 patients présentant une histologie négative 27 étaient HpSA-négatifs. Comparativement au test de référence, ce test antigénique a fait preuve d'une sensibilité et d'une spécificité peu convaincantes, à savoir respectivement $54,8 \%$ et $79,4 \%$, les valeurs prédictives positive et négative étant quant à elles de $82,9 \%$ et $49,9 \%$. Toutefois, ce test peut avoir son utilité dans le cadre d'un dépistage de masse d'Helicobacter pylori.
\end{abstract}

${ }^{1}$ Department of Paediatric Gastroenterology, Liver and Gastrointestinal Diseases Research Centre, ${ }^{2}$ Department of Microbiology, Children's Hospital, Tabriz University of Medical Sciences, Tabriz, Islamic Republic of Iran (Correspondence to M. Rafeey: mrafeey@yahoo.com).

Received: 22/07/05; accepted: 13/11/05 


\section{Introduction}

Gastric and ulcer peptic disease is a common disease in the community, especially in children. Considering the close relationship between peptic ulcer and gastritis caused by Helicobacter pylori, the accurate and early diagnosis of infection by this micro-organism is very important so as to provide prompt and convenient treatment to the affected children $[1,2]$. The diagnostic tests for $H$. pylori infection are principally of 2 types: invasive and non-invasive. Invasive diagnostic methods include polymerase chain reaction (PCR), rapid urease test (RUT), endoscopy of the upper digestive tract and biopsy of the gastric mucosa for pathological examination. Non-invasive diagnostic methods include serologic enzyme-linked immunosorbent assay (ELISA), urea breath test (UBT) with $\mathrm{C} 13$ or $\mathrm{C} 14$ labelled urea and the $H$. pylori stool antigen test (HpSA) [1-4].

No study is available from the East Azerbaijan area or elsewhere in the Islamic Republic of Iran to compare the results of invasive and non-invasive diagnostic methods for detecting of $H$. pylori antigen in stool samples in children in the community. This research study was therefore carried out to ascertain whether detection of $H$. pylori antigen in the stool sample using immunoassay can substitute for diagnostic tests such as endoscopy and biopsy of the gastric mucosa, which, although standardized, are painful procedures that may involve a high level of risk, especially in children.

\section{Methods}

The study design was observational, descriptive with convenience sampling.

\section{Sample}

The study was carried out on all children aged from 1-15 years old with dyspeptic symptoms who were referred to the endoscopic section of Tabriz children's hospital during an 11-month period from May 2003 to March 2004. The children were included if they suffered dyspepsia, chronic gastric pain (gastric pain for more than 3 months with at least one course of pain each month), recurrent anorexia, vomiting and heartburn, bleeding in the upper or lower digestive tract and recurrent diarrhoea. Patients with severe diarrhoea and those who had received antibiotics or proton pump inhibitors as well as antacids in the previous 4 weeks were excluded from the study.

The children and their parents were informed about the necessary clinical and laboratory examination procedures and their consent was taken before the start of the study.

\section{Data collection}

Endoscopy of the digestive system was performed by video endoscopy (Olympus video-gastroscope Evis 100 type XP 20). A total of 3 biopsy samples were taken from observation areas and sent to the pathology laboratory: 2 from the antrum at $2 \mathrm{~cm}$ intervals and 1 from the gastric corpus. Histological preparations were done under haematoxylin-eosin stain and also by modified May-Grunwald-Giemsa staining procedure. The presence of $H$. pylori organisms was reported in 6 groups ranging from grade 0 to grade 5 using the modified scoring system (MSS) criteria for assessing histopathology samples [5].

Stool samples for the HpSA test were taken from patients and sent to the microbiology laboratory. Detection of $H$. pylori 
antigens in stool was carried out by ELISA polyclonal antibody test (Equipar HpSA test, Saronno, Italy).

\section{Analysis}

After gathering simple frequencies and percentages, the data were transferred to computer and analysed by SPSS using McNamara test and the chi-squared test. Sensitivity, specificity and positive and negative predictive values were calculated using the histopathology results as the gold standard.

\section{Results}

The study group was 96 children aged from $1-15$ years old with a mean age of 8.3 years (standard deviation 0.3 years); 70 (72.9\%) were outpatients and $26(27.1 \%)$ were admitted as inpatients in the gastroenterology division or other divisions of the children's hospital. There were 65 males $(67.7 \%)$ and 31 females $(32.3 \%)$.

Table 1 shows the results of histopathology examination of biopsy specimens from the gastric areas. The results of the HpSA antigen test in stool samples of patients are shown in Table 2.

Comparing the incidence of $H$. pylori cases from biopsy and stool testing, it was found that out of $62(64.6 \%)$ patients re-

\begin{tabular}{|c|c|c|c|}
\hline $\begin{array}{l}\text { Biopsy } \\
\text { grades }\end{array}$ & $\begin{array}{l}\text { No. of } \\
\text { children }\end{array}$ & $\%$ & $\begin{array}{c}\text { Total \% } \\
\text { (MSS criteria) }\end{array}$ \\
\hline 0 & 34 & 35.4 & 35.4 \\
\hline 1 & 22 & 22.9 & 58.3 \\
\hline $2 \& 3$ & 31 & 32.3 & 90.6 \\
\hline $4 \& 5$ & 9 & 9.4 & 100.0 \\
\hline Total & 96 & 100.0 & \\
\hline
\end{tabular}

Table 2 Frequency of children positive by Helicobacter pylori stool antigen (HpSA) test, based on modified scoring system (MSS) criteria

\begin{tabular}{lcrc}
\hline Test & $\begin{array}{c}\text { No. of } \\
\text { children }\end{array}$ & $\%$ & $\begin{array}{c}\text { Total \% } \\
\text { (MSS criteria) }\end{array}$ \\
\hline HpSA negative & 55 & 57.3 & 57.3 \\
HpSA positive & 41 & 42.7 & 100.0 \\
Total & 96 & 100.0 & \\
\hline
\end{tabular}

ported positive for H. pylori in histopathology of biopsy samples (the gold standard), only 34 cases were $H$. pylori positive by the HpSA test (Table 3). According to this study, the sensitivity, specificity, positive and negative predictive values for the HpSA test were $54.8 \%, 79.4 \%, 82.9 \%$ and $49.9 \%$ respectively. There was a significant difference between the 2 groups who were positive for $H$. pylori in biopsy sample and negative for $H$. pylori in biopsy in terms of H. pylori variance in the HpSA test $(P<$ 0.001, McNamara test).

Table 4 presents the $H$. pylori histopathology grading in biopsy samples based on MSS criteria and the HpSA positive cases. It was observed that as the grade of $H$. pylori in biopsy samples increased, the possibility of the stool sample being positive increased too $(P<0.001)$. Out of 31 patients whose histological examination indicated

\begin{tabular}{|c|c|c|c|}
\hline \multicolumn{4}{|c|}{$\begin{array}{l}\text { Table } 3 \text { Comparison of frequency of children } \\
\text { positive by histopathology of gastric biopsy } \\
\text { (gold standard) and Helicobacter pylori stool } \\
\text { antigen (HpSA) test }\end{array}$} \\
\hline Test & $\begin{array}{l}\text { Biopsy } \\
\text { negative } \\
\text { No. }\end{array}$ & $\begin{array}{c}\text { Biopsy } \\
\text { positive } \\
\text { No. }\end{array}$ & $\begin{array}{l}\text { Tota } \\
\text { No. }\end{array}$ \\
\hline HpSA negative & 27 & 28 & 55 \\
\hline HpSA positive & 7 & 34 & 41 \\
\hline Total & 34 & 62 & 96 \\
\hline
\end{tabular}




\begin{tabular}{|c|c|c|c|c|c|}
\hline \multirow[t]{2}{*}{$\overline{T e s t}$} & \multicolumn{5}{|c|}{ Biopsy grades } \\
\hline & $\begin{array}{c}0 \\
\text { No. }\end{array}$ & $\begin{array}{c}1 \\
\text { No. }\end{array}$ & $\begin{array}{r}2 \& 3 \\
\text { No. }\end{array}$ & $\begin{array}{c}4 \& 5 \\
\text { No. }\end{array}$ & $\begin{array}{c}\text { Total } \\
\text { No. }\end{array}$ \\
\hline HpSA negative & 27 & 14 & 14 & 0 & 55 \\
\hline HpSA positive & 7 & 8 & 17 & 9 & 41 \\
\hline Total & 34 & 22 & 31 & 9 & 96 \\
\hline
\end{tabular}

grade 2 or 3 , less than of half cases $(n=14)$ were $H$. pylori negative in stool samples. The most important finding was that all of 9 patients determined as grade 4 or 5 from biopsy samples were also $H$. pylori positive in stool samples (Table 4). In addition, out of all 34 cases of grade 0 of $H$. pylori in biopsy sample, 27 cases were reported $H$. pylori negative.

\section{Discussion}

To determine H. pylori infection in humans, multiple laboratory methods have been reported [5-8]; however, based on estimated resources, the histological examination of biopsy samples is considered as the gold standard among invasive diagnostic methods to diagnose this micro-organism with a sensitivity and specificity of $100 \%$ [2].

In comparison to biopsy, cultivation of bacteria requires specific environmental conditions and a fairly long time for the organism to grow, which are considered as the shortcomings of the biopsy cultures, although the rate of success is reported to be nearly $100 \%$ when there is accuracy in the cultivation of biopsy samples [2]. Other invasive procedures, the RUT and antibody measurements in blood using ELISA are less sensitive and specific in children as compared with adults $[1,2]$.

The UBT is a non-invasive method that possesses more accuracy to diagnose infectious from non-infectious cases in children and adults and is reported to be $100 \%$ sensitive and $92 \%$ specific in diagnosing $H$. pylori infection in children. However, the test is difficult to perform in children and require the child's collaboration [2].

According to a study in Taiwan, 53 children affected by dyspepsia were assayed [ 6 ]. The diagnostic accuracy of different tests was as follows: culture $98.1 \%$, RUT 96.2\%, pathology 98.1\%, PCR 94.3\%, serology $84.9 \%$, UBT $100 \%$ and HpSA $96.2 \%$. According to their study, all the above-mentioned methods, except serology, are considered valuable diagnostic methods in the diagnosis of H. pylori in children [6]. This and similar studies in Germany, China, France, England, Spain, Italy and Poland revealed that non-invasive methods such as HpSA possess high sensitivity and specificity as compared with other diagnostic methods in children such as UBT [7-15].

In another study in England, the results of detection of HpSA were compared in 72 patients suffering from dyspepsia using 3 stool antigen enzyme immunoassay kits versus endoscopy biopsy samples [16]. The sensitivity of the Premier Platinum Hp SA kit (Meridian Diagnostics, Cincinnati, Ohio, USA) was $63.6 \%$ and specificity $92.6 \%$, the sensitivity of FemtoLab Cnx kit (Dako, Ely, Cambridgeshire, UK) was $88 \%$ and specificity $97.6 \%$, and the sensitivity of the Hp Ag kit (Dia.Pro, Milan, Italy) was $56 \%$ and specificity $97.6 \%[16]$.

Our study was an HpSA test using polyclonal antibody detected by ELISA and the sensitivity and specificity were $54.8 \%$ and $79.4 \%$ respectively. Our results are compatible with the above study [16] but not with the results of the study in 
Taiwan [6]. Despite minor difficulties such as the collection of a new stool sample, the performance of $\mathrm{HpSA}$ is an alternative and reliable substitute for the UBT test as a non-invasive diagnostic method in children. Secondly, the test is not expensive and does not require a blood sample.

Considering the sensitivity and specificity of the HpSA test in our study, the practical value of this test seems to lie more in eliminating cases that are negative for $H$. pylori and accordingly this test could be ap- plied in mass screening such as at regional school level.

\section{Acknowledgements}

The authors wish to thank the office of the Vice-Chancellor for Research of Tabriz University of Medical Sciences for the financial assistance and Dr Hasani and Ms Anbarshahi for preparation of this article.

\section{References}

1. Sylvester FA. Peptic ulcer disease. In: Behrman RE, Kilgman RM, Jenson HB, eds. Nelson textbook of pediatrics, 17 th ed. Philadelphia, WB Saunders, 2004:1244-7.

2. Rowland M, Bourke B, Drumm B. Gastritis and peptic ulcer disease. In: Walker WA et al., eds. Pediatric gastrointestinal disease, 3rd ed. Ontario, BC Decker, 2000:385-92.

3. Antonioli DA, Odze RD. Gastritis in infants and children. In: Graham DY, Genta RM, Dixon MF, eds. Gastritis. Philadelphia, Lippincott, Williams and Wilkins, 1999.

4. Triantafyllopoulou M, ed. Helicobacter pylori infection. eMedicine [online article] (http://www.emedicine.com/ped/topic938. htm, accessed 16 March 2007).

5. Sheu BS et al. Bacterial density of Helicobacter pylori predicts the success of triple therapy in bleeding duodenal ulcer. Gastrointestinal endoscopy, 1996, 44:683-8.

6. $\mathrm{Ni} \mathrm{YH}$ et al. Accurate diagnosis of Helicobacter pylori infection by stool antigen test and 6 of other current available tests in children. Journal of pediatrics, 2000 , 136(6):823-7.

7. Braden B et al. New immunoassay in stool provides an accurate noninvasive diagnostic method for Helicobacter pylori screening in children. Pediatrics, 2000, 106:115-7.

8. Shepherd AJ et al. Comparison of an enzyme immunoassay for the detection of Helicobacter pylori antigens in the faeces with the urea breath test. Archives of disease in childhood, 2000, 83(3):268-70.

9. Husson MO et al. Evaluation of a Helicobacter pylori stool antigen test for the diagnosis and follow-up of infections in children. European journal of clinical microbiology \& infectious diseases, 2000 , 19(10):787-9.

10. Gonzalez-Cuevas A et al. Infecciones por Helicobacter pylori: deteccion de antigeno en muestras fecales [Helicobacter pylori infections: antigen detection in stool samples]. Enfermedades infecciosas y microbiologia clinica, 2001, 19(2):49-52.

11. Sykora J et al. Presna neinvazivni diagnostika infekce Helicobacter pylori pomoci stanoveni antigenu ve stolici $v$ detske populace [Accurate noninvasive diagnosis of Helicobacter pylori infection using antigen determination in the feces in the pediatric population]. Casopis lekaru ceskych, 2002, 141(13):425-7.

12. Roggero $P$ et al. Helicobacter pylori stool antigen test: a method to confirm eradi- 
cation in children. Journal of pediatrics, 2002, 140:775-7

13. Van Doorn OJ et al. Helicobacter pylori stool antigen test: a reliable non-invasive test for the diagnosis of Helicobacter pylori infection in children. European journal of gastroenterology \& hepatology, 2001, 13(9):1061-5.

14. Koletzko $S$ et al. Evaluation of a novel monoclonal enzyme immunoassay for detection of Helicobacter pylori antigen in stool from children. Gut, 2003, 52(6):8046.

15. Sykora J et al. Diagnostika infekce Helicobacter pylori $v$ detskem veku novou enzymoimunoanalytickou metodou stanovenim antigenu ve stolici (HpStAR) pomoci monoklonalnich protilatek [Diagnosis of Helicobacter pylori infection in childhood with a novel immunoenzyme method (HpStAR) which detects antigens in feces using monoclonal antibodies]. Casopis lekaru ceskych, 2003, 142(11):687-90.

16. Andrews $\mathrm{J}$ et al. Comparison of three stool antigen tests for Helicobacter pylori detection. Journal of clinical pathology, 2003, 56:769-71.

\section{Research policy and cooperation in the Eastern Mediterranean Re-} gion

The Research Policy and Cooperation (RPC) unit of the WHO Eastern Mediterranean Region aims to support health research and development in Member States of the Region through policy advice, capacity building of national health research systems, generation of appropriate knowledge and its utilization towards improved health.

RPC works in close collaboration with the technical units in the WHO Eastern Mediterranean Regional Office as well as national focal points for research or medical research councils and major health research institutions in the Region and other national and international partners.

Further information about the work RPC is available at: http://www. emro.who.int/rpc/index.htm 